\title{
Transversopontis omarians sp.nov. Calcareous Nannofossils from Jaddala Formation (Eocene) in Dh.1 well, central Iraq
}

\author{
Omar A. Al-Badrani \\ Mohammad H. Al-Ubaidi \\ Department of Geology \\ College of Science \\ University of Mosul
}

(Received 22/3/2012, Accepted 7/5/2012)

\begin{abstract}
ABSITRACT
Transversopontis omarians sp.nov. is described from Jaddala Formation (Eocene) in Dh.1well, central Iraq. This species is recognized by having elliptical muroliths with transverse bar lacking two openings in the ends of the central area, it is reaching about 10 microns in length.

Transversopontis omarians sp.nov. من متحجرات النانو الكلسية من تكوين جدالة(الايوسين) في بئر ظفرية- ا وسط العراق

محمد حازم العبيدي قسم علوم الأرض أنس

كلبة العلوم جامعة الموصل

الملخص

تم وصف النوع .Transversopontis omarians sp.nov من تكوين جدالة (الايوسين) في بئر

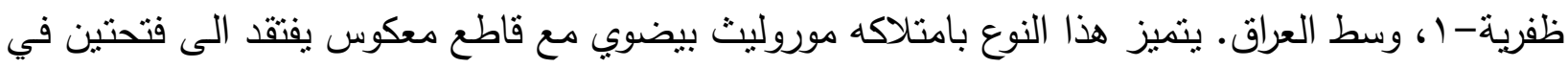
جانبي المنطقة المركزية، ويصل طوله الى حوالي ـ الميكرون.
\end{abstract} \footnotetext{
عمر احمد الببراني

\section{STRATIGRAPHIC REMARKS}

Jaddala Formation was first described by Henson, 1940 (in Bellen et al.,1959) near Jaddala village at southern limb of Sinjar anticline NW Iraq, it is about $342 \mathrm{~m}$. in thickness and consists of marly limestone, chalky limestone and Marlstone (Bellen et al.,1959).
} 
The described species come from Jaddala Formation from sample at depth 2505 metres in Dh.1 well at central Iraq (Fig. 1), which was drilled by I.N.O.C. and determinate Aaliji Formation between depths (2675-2525) consist of limestone, shaley limestone and shales, and determinate Jaddala Formation between depths (2525 - $2375 \mathrm{~m}$.) consist limestone, marly limestone and chalky limestone (Aziz, 1997).

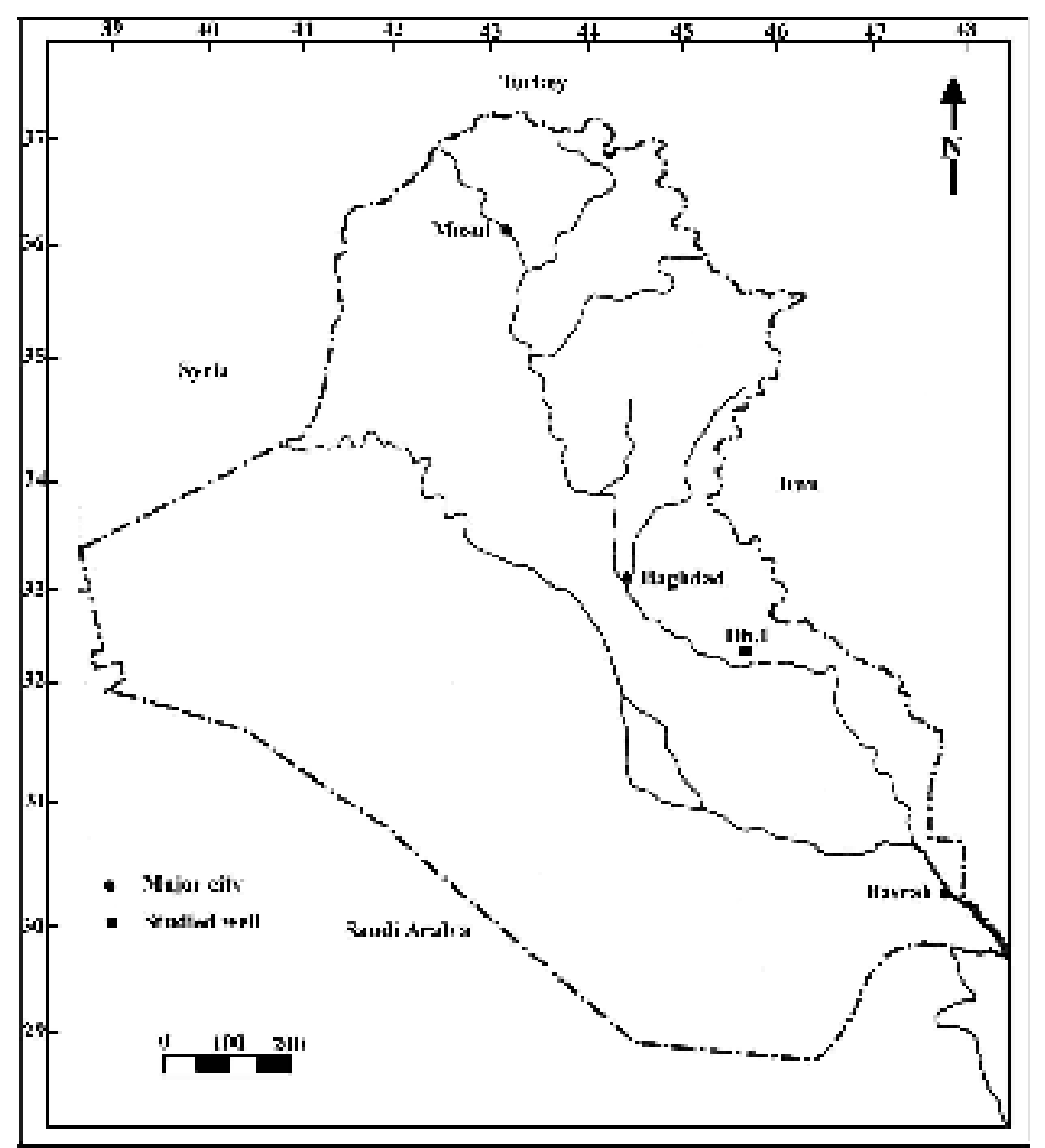

Fig. 1: Location Map of Studied Subsurface Section.

\section{SYSTEMATIC PALEONTOLOGY}

The Classification was based on Perch-Nielsen (1985), Young et al., (1997) and Young and Bown, (1997):

Kingdom Protista

Division: Chrysophyta Rothmaler, 1949

Class: Coccolithophyceae Rothmaler, 1949

Family: Pontosphearaceae Lemmermann, 1908

Genus: Transversopontis Hay, Mohler and Wide,1966 
Type species: Discolithus obliquipons(Deflandre and Fert, 1954) Hay, Mohler and Wide, 1966

\section{Transversopontis omarians sp.nov.}

Pl. 1, Figs. 1 - 3

Holotype: Mos.Geo.N.T.(2505-1,2) ( Mos: Mosul; Geo: Dept. of Geology; N.T.: Nannofossils Tertiary collection).

Type locality and Stratum: Southeast Baghdad, Central Iraq, Jaddala Formation from Marly Limestone from the depth 2505 metres in Dh.1 well at central Iraq.

Materials Examined: Two Heterococcoliths elliptical coccoliths.

Dimensions: Longitudinal (10micron),Traverse(6micron), traverse bar (7 micron).

Diagnosis: Elliptical muroliths with transverse bar does not have two openings in the ends of the central area.

Description: Heterococcoliths elliptical muroliths with an outer rim-cycle of V-units showing imbrication form narrow outer rim-cycle, central-area spanned by a conjunct bar, usually oblique, the bar do not have two openings in the ends of the central area (Plate 1).

Discussion: The Transversopontis Hay, Mohler and Wide,1966 have fourteen species(see Appendix), the Iraqi species very close to Transversopontis obliquipons (Deflandre in Deflandre and Fert, 1954) Hay, Mohler and Wade, 1966, but the later differs in having openings in the ends of the central area, and it is isogyre is not the same. Furthermore, it is similar to isogyre of Transversopontis zigzag Roth and Hay, 1967 but the later without straight bar as in the studied species (Plate 2) (Perch-Nielsen, 1985) (Farrinacci, 1970).

Derivation of name: From the name of Professor Dr. Farouk S. Al-Omari for his contribution to the Micropaleontological studies in Iraq. 
The recorded species of Transversopontis Hay, Mohler and Wide,1966 until now are fourteens species these are:

Transversopontis duocavus (Bramlette and Sullivan, 1961)Locker, 1973

Transversopontis exilis (Bramlette and Sullivan, 1961)Perch - Nielsen, 1971

Transversopontis fimbriatus(Bramlette and Sullivan, 1961) Locker, 1968

Transversopontis latus Muller, 1970

Transversopontis obliquipons (Deflandre in Deflandre and Fert, 1954) Hay, Mohler and Wade, 1966

Transversopontis pax Stradner and Seifert, 1980

Transversopontis prava Locker, 1967

Transversopontis pseudopulcher Perch - Nielsen, 1967

Transversopontis pulcher (Deflandre in Deflandre and Fert, 1954) Perch - Nielsen, 1967

Transversopontis pulcheroides (Sullivan, 1964) Baldi - Beke, 1971

Transversopontis pygmaea (Locker, 1967) Perch - Nielsen, 1984

Transversopontis rectipons (Haq, 1968) Roth, 1970

Tansversopontis sigmoidalis Locker, 1967

Transversopontis zigzag Roth and Hay, 1967

\section{REFERENCIS}

Aziz, N. M., 1997. Paleocene-Eocene Ostracoda from Selected Wells in West, North and Middle Iraq. Unpublished Ph.D. Thesis, Mosul University, Mosul. Iraq.

Bellen, R. C. Van., Dunnington, H. V., Wetzel, R. and Morton, D. M., 1959. Lexique Stratigraphic International, V.III: Asie, Fasc. 10 a, Iraq. 333p.

Farrinacci, A., 1970. Catalogue of Calcareous Nannofossils.(ed.) Tecnoscienza, Rome.

Perch-Nielsen, K., 1985. Cenozoic Calcareous Nannofossils. In Bolli, H. M., Saundes, J. B., and Perch-Nielsen, K. (eds.), Plankton Stratigraphy. Cambridge University Press,Cambridge, pp. 427 - 554.

Young, J. R. and Bown, P. R., 1997. Cenozoic Calcareous Nannoplankton Classification. Journal of Nannoplankton Research, Vol. 19, pp. 36 - 47.

Young, R. J., Bergen, J. A., Burnett, Fiorentino, A., Jordan, R. W., Kleijne, A., Niel, B. E., Romein, A. J. and Salis, K. V., 1997. Guidelines for Coccolith and Calcareous Nannofossils Terminology. Paleontology, Vol. 40, Part 4, pp. 875 - 912. 


\section{ACKNOWLEDGMENT}

We would like to express our thanks to Dr. Nisreen Mallah Aziz / Dept. of Geology/Science College/Mosul University who Provided us with the samples of the present study.

\section{Plate 1}

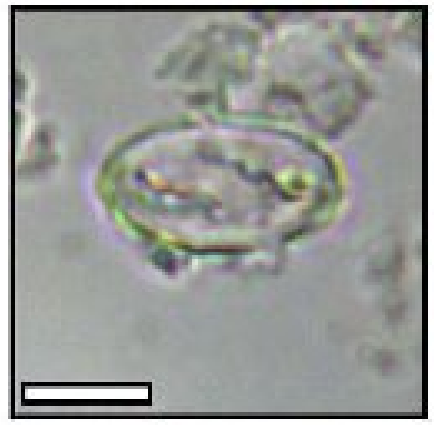

liy.l: Transversopontis omarians sp.now. momnal light. bar is 5 mikion

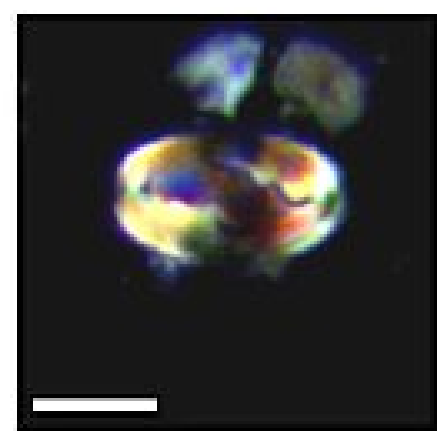

Fig. 2: Transversopontis amarians sp.noy.

polarized light, bar is 5 micron

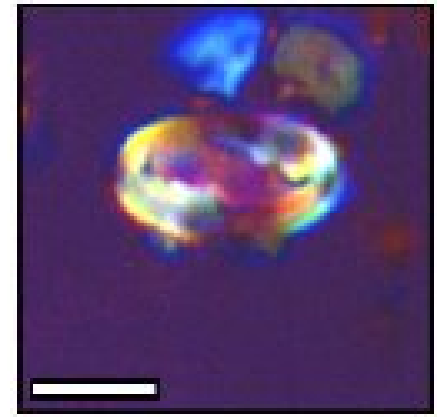

lïg, 3: Transwersopontis omarians sp.nov.

yypsum platc, bar is 5 micron 
Omar A. Al-Badrani and Mohammad H. Al-Ubaidi

\section{Plate 2}

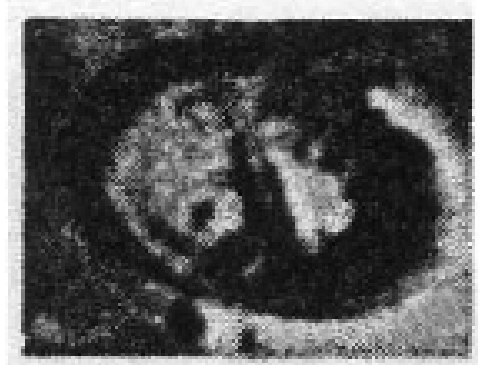

liig. 1+ Transwersopontis obliquipons

(Deflandre) Hay; Mohler and Wade, 1966 uorual light

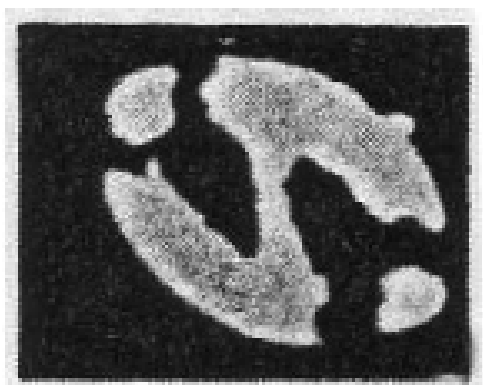

1. ig. 2: Transwersopontis ohtiquipons

(Deflandre) Hay, Mohler and Wade, 196r, polarizet lighul

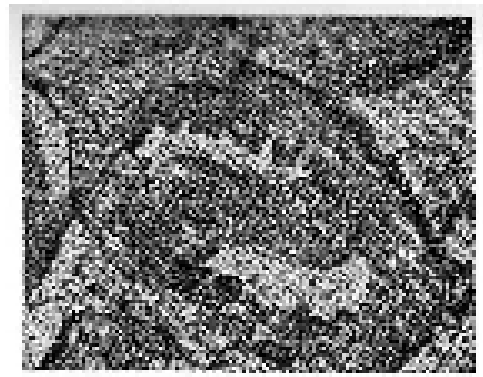

lig.3: Trunswersopunfs aigzay

Roth and II ay, 1967

ronnt] lightl 